\title{
In situ hybridisation detects pro-apoptotic gene expression of a Bcl-2 family member in white syndrome-affected coral
}

\author{
T. D. Ainsworth ${ }^{1, *}$, B. Knack ${ }^{2}$, L. Ukani ${ }^{2}$, F. Seneca ${ }^{1}$, Y. Weiss ${ }^{2}$, W. Leggat ${ }^{1,2}$ \\ ${ }^{1}$ ARC Centre of Excellence for Coral Reef Studies, James Cook University, Townsville, Queensland 4810, Australia \\ ${ }^{2}$ Comparative Genomics Centre, School of Pharmacy and Molecular Sciences, James Cook University, Townsville, \\ Queensland 4810, Australia
}

\begin{abstract}
White syndrome has been described as one of the most prolific diseases on the Great Barrier Reef. Previously, apoptotic cell death has been described as the mechanism driving the characteristic rapid tissue loss associated with this disease, but the molecular mechanisms controlling apoptotic cell death in coral disease have yet to be investigated. In situ methods were used to study the expression patterns of 2 distinct regulators of apoptosis in Acropora hyacinthus tissues undergoing white syndrome and apoptotic cell death. Apoptotic genes within the Bcl-2 family were not localized in apparently healthy coral tissues. However, a Bcl-2 family member (bax-like) was found to localize to cells and tissues affected by white syndrome and those with morphological evidence for apoptosis. A potential up-regulation of pro-apoptotic or bax-like gene expression in tissues with apoptotic cell death adjacent to disease lesions is consistent with apoptosis being the primary cause of rapid tissue loss in coral affected by white syndrome. Pro-apoptotic (bax-like) expression in desmocytes and the basal tissue layer, the calicodermis, distant from the disease lesion suggests that apoptosis may also underlie the sloughing of healthy tissues associated with the characteristic, rapid spread of tissue loss, evident of this disease. This study also shows that in situ hybridisation is an effective tool for studying gene expression in adult corals, and wider application of these methods should allow a better understanding of many aspects of coral biology and disease pathology.
\end{abstract}

KEY WORDS: Gene expression - In situ hybridisation - Coral disease - White syndrome · Apoptosis · Acropora

- Resale or republication not permitted without written consent of the publisher

\section{INTRODUCTION}

As in many ecosystems worldwide, diseases are considered a major threat to coral reefs (Harvell et al. 2002, Sutherland et al. 2004, Krediet et al. 2013). Increases in diseases have been linked to increasing environmental stressors, including pollution, water quality and thermal stress (Mouchka et al. 2010, Mydlarz et al. 2010, Ban et al. 2014). However, despite many attempts to link specific pathogens to specific diseases of reef-forming corals, few have been iden- tified, and reduced host resistance (and a resultant opportunistic pathogenesis) is considered an underlying cause of many coral disease outbreaks (Lesser et al. 2007). Much of the confusion in identifying disease causation in corals is due to the very similar macroscopic signs that are evident during the onset and progression of disease in a coral colony, even in situations where very different underlying cellular and molecular changes are occurring (Ainsworth et al. 2007a, Work et al. 2008, Pollock et al. 2011). In addition, the macroscopic disease signs, which 
include characteristics such as lesion and tissue colour, can vary depending on the stage of disease, the environmental conditions and the progression of the disease in a particular coral host (Pollock et al. 2011). Adding to the current difficulties in coral disease diagnosis is a limited understanding of the cellular changes that occur during various diseases (Ainsworth et al. 2007a, Palmer et al. 2011, Work \& Meteyer 2014).

Our current understanding of coral immunity is primarily limited to the identification of genes and proteins with homology to those of higher organisms (Miller et al. 2007, Mydlarz et al. 2010). However, recent studies have begun to characterize the immune system pathways specific to coral disease events (Dishaw et al. 2005, Mydlarz \& Harvell 2007, Kvennefors et al. 2008, van de Water et al. 2015). For example, granular haemocytes are proposed to carry components of the prophenoloxidase cascade within the sea fan Gorgonia ventalina (Mydlarz \& Harvell 2007). Palmer et al. (2010) also identified components of the prophenoloxidase cascade and investigated melanin production in 10 families of corals on the Great Barrier Reef (GBR). Kvennefors et al. (2008, 2010a) further identified immune functioning lectin and complement factor C3-like proteins in the model coral Acropora millepora. Studies such as these are now identifying components of the coral immune system, but the exact functional role and cellular localization for the vast majority of identified orthologues in the coral host immune response have not yet been determined. Very little is currently known of coral cell-specific immune reactions or cell-specific responses to disease. Differentiating and localizing specific immune functioning cells and tissues within the coral host, and understanding functions during coral disease events, will provide a clearer understanding of the host responses and the progression of disease within a coral colony.

In recent years, white syndrome, a term coined to describe a disease resulting in a characteristic pattern of tissue loss, has been identified as the most prevalent disease on the GBR (Willis et al. 2004, Ainsworth et al. 2007b, Roff et al. 2008b, Sussman et al. 2008). White syndrome is characterized by high rates of tissue loss, with up to $5 \%$ of total coral tissue biomass lost within days of the disease initiating (Roff et al. 2006). This rapid tissue loss exposes the underlying white calcium carbonate skeleton in a characteristic radial pattern, which gives rise to the disease name. While potential pathogens have been proposed in some cases of white syndrome (Sussman et al. 2008), other studies have found that microbial in- volvement is not evident in situ during the period of rapid tissue loss associated with the disease (Ainsworth et al. 2007b, Kvennefors et al. 2010b). Additionally, ecological evidence suggests that environmental stress plays a key role in the occurrence of white syndrome disease outbreaks (Bruno et al. 2007, Ban et al. 2014).

Other than evidence for extensive apoptotic cell death of the host tissue, very little is known of the molecular mechanisms underlying the characteristic rapid tissue loss associated with white syndrome (Ainsworth et al. 2007b). In higher organisms, a complex network of pro- and anti- apoptotic genes provides fine control of cell death in an organism in response to both biotic and abiotic cues (for reviews see Ayres 1984, Chao \& Korsmeyer 1998, Weinrauch \& Zychlinsky 1999, Deponte \& Becker 2004, David et al. 2005, Kültz 2005, Elmore 2007). However, despite the increasing understanding of the complexity of lower metazoan apoptosis (see reviews by Zmasek et al. 2007, Czabotar et al. 2014), the molecular pathways which govern apoptotic cell death in coral disease and mortality are not well documented. Bcl-2 family members comprise molecular machinery integral to the control of the fate of cells and the occurrence of apoptosis. The interactions of bcl-2 family members function as upstream regulators of mitochondrial outer membrane permeability, the release of cytochrome $\mathrm{C}$ to trigger the apoptosis cascade and caspase activation. Key members of the $b c l-2$ family of cell death regulators, including $b c l-2$, $b c l-x$, and $b a x$-like, have been identified in the corals A. millepora and $A$. aspera. These homologues have been shown to have sequence conservation in the key regulatory domains governing apoptotic cell death, including the BH-1, $-2,-3$ and -4 domains necessary for function (Ainsworth et al. 2008, 2011, Pernice et al. 2011). As occurs in higher metazoans, the $b c l-2$ family proteins are likely to function as apoptosis regulators in corals, and act as a death switch.

Methods to localize cell- and tissue-specific patterns of gene expression have been widely applied in other systems as a means to determine the cellular function, infer gene function and aid in understanding organism biology. In situ hybridisation (ISH) is a valuable method with which to detect temporal and spatial gene expression patterns on a cellular level by hybridising labelled complementary RNA or cDNA probes to specific expressed genes of interest (Brown 1998, Levsky \& Singer 2003). The development of these technologies has led to the multi-disciplinary application of ISH for localizing and quantify- 
ing gene expression within cells (Itzkovitz \& van Oudenaarden 2011, Wunderlich et al. 2014). ISH has been applied to veterinary pathology (for a review, see Brown 1998) and has been used in the study of developmental processes in larval marine invertebrates (Grasso et al. 2011). The ability to localize gene expression provides a way to link responses at the molecular and cellular level to the organismal responses. Here, we describe the application of ISH to adult coral tissues to investigate cell- and tissuespecific apoptotic gene expression during disease progression. By understanding the molecular mechanisms governing coral host responses during disease, we can better understand the underlying causes of tissue loss and the role of coral defenses in disease and mortality.

\section{MATERIALS AND METHODS}

\section{Sample collection, fixation and processing}

Branches of Acropora millepora ( $\mathrm{n}=6$ ) were collected from the reef flat and slope of reefs (depth of less than $3 \mathrm{~m}$ ) adjacent to Heron Island on the southern GBR $\left(23.44^{\circ} \mathrm{S}, 151.91^{\circ} \mathrm{E}\right)$, for use in the development of an ISH protocol to use with coral tissues. Fragments $(7 \mathrm{~cm})$ from both white syndrome-affected ( $\mathrm{n}=6$ ) and healthy $(\mathrm{n}=6)$ colonies of $A$. hyacinthus were also collected using SCUBA from the nearby Heron Island reef slope (depth of 10-15 m). Following collection from the reef, samples $\left(5 \mathrm{~cm}^{2}\right)$ were taken from the disease lesions (interface of exposed skeleton and coral tissue) of diseased coral colonies and from comparable regions of apparent healthy A. hyacinthus fragments (differentiating the coral colony into center colony, mid-colony and colony tip regions). The coral samples collected from both coral species were fixed individually in $50 \mathrm{ml}$ of $4 \%$ paraformaldehyde (Electron Microscopy Services) in DNase/RNase-free phosphate-buffered saline (PBS, $\mathrm{pH}$ 7.4) (distilled water DNase/RNase-free GIBCO $500 \mathrm{ml}$ and Roche $10 \times 4$ l). Following fixation, samples were washed in DNase/RNase-free PBS solution and stored in 50\% ethanol:DNase/RNase-free PBS solution for transport. The coral samples were decalcified in DNase/RNase-free 20\% EDTA (pH 7.4) at $4^{\circ} \mathrm{C}$ with constant rocking and then processed for paraffin embedding. Processing required washes in $50 \%$ ethanol $(\mathrm{EtOH}), 70 \% \mathrm{EtOH}, 95 \% \mathrm{EtOH}(\times 3)$, $100 \%$ EtOH $(\times 3)$, xylene $(\times 3)$ and infiltration with molten paraffin $(\times 3)$, prior to embedding in molten paraffin.

\section{In situ end labeling to determine presence of apoptotic cells}

The presence or absence of apoptotic cells within white syndrome tissue samples was confirmed using the in situ end labeling (ISEL) ApopTag Plus peroxidase in situ Apoptosis Kit (Chemicon International) as per the manufacturer's instructions. Adjacent tissue sections were also stained with Harris's haematoxylin and eosin (Sigma-Aldrich), Masson's Trichrome (ProSciTech) and Alcian Blue/periodic acid-Schiff (ProSciTech) to determine tissue structures and evidence for necrosis of tissues. All tissue sections were permanently mounted following colour development.

\section{RNA extraction, cDNA synthesis and bcl-2 family gene sequencing in A. hyacinthus}

Samples of freshly collected healthy A. hyacinthus were snap frozen in liquid nitrogen. The coral samples were crushed on dry ice, RNA was extracted using a Qiagen RNAeasy mini kit, and cDNA synthesis was conducted using the Qiagen QuantiTect Rev transcription kit as per the manufacturer's instructions. Primers for $b c l-2(\mathrm{Bcl} 2-\mathrm{F}$, ATT TGA TTC TCT AGT GTG GTT TA; Bcl2-R, CGA GAA TGG CGG ATG GGA AGG; generating a 1081 bp product) and bax-like (BaxF, GGC GAG TGG CGG ACG AAC; BaxR, ATT TGA TTC TCT AGT GTG GTT TA; generating a $461 \mathrm{bp}$ product) were designed from gene alignments from $A$. aspera and $A$. millepora. PCR fragments were cloned and sequenced to confirm their identity and homology within the $\mathrm{BH}$ domains.

\section{RNA probe generation and DIG labelling}

PCR fragments were cloned and used for the generation of RNA probes using the Roche Digoxigenin (DIG) RNA Labeling Kit (SP6/T7), as per the manufacturer's instructions. Both sense (negative control) and anti-sense probes were generated for key $b c l-2$ family members. Gene homologues of apextrin and a cadherin (adhesion) molecule (AM-Cadherin-A) (Miller et al. 2007, B. Knack et al. unpubl. data) were identified from $A$. millepora expressed sequence tag (EST) and 454-sequencing databases (D. Miller et al. unpubl. data), for use as control genes in the optimization of ISH labeling protocols. Sequence comparisons for both genes of interest are provided and the homologous regions within $\mathrm{BH}$ domains are highlighted (Table 1). All tissue sections were perma- 
Table 1. Acropora Bcl-2 family gene and gene probe schematic. Triangles: locations of start and stop codons

\begin{tabular}{|lcc|}
\hline $\begin{array}{l}\text { Bcl-2 family } \\
\text { member }\end{array}$ & $\begin{array}{c}\text { Sequence structure } \\
\text { Probe location }\end{array}$ & $\begin{array}{c}\text { Sequence } \\
\text { length (bp) }\end{array}$ \\
Pro-apoptotic & & 330 \\
Anti-apoptotic & & 4615 \\
bcl2 probe & & 4
\end{tabular}

nently mounted following colour development. Primer sequences include bax-like (BaxF1: AAT TAA TCC GTC CGC GAA AGT CT; BaxR1: GTC GGG GTG TTC AGC CTC CAT) and bcl-2-like (Bcl2F1; Bcl2-F: ATT TGA TTC TCT AGT GTG GTT TA; Bcl2F2: CGA GAA TGG CGG ATG GGA AGG).

\section{Cell- and tissue-specific gene expression patterns using ISH}

Paraffin-embedded coral samples were sectioned at $7 \mu \mathrm{m}$, collected onto Menzel Superfrost Plus microscope slides (Menzel, SF41296SP), dried overnight at $37^{\circ} \mathrm{C}$ and stored at $-20^{\circ} \mathrm{C}$. On the day of ISH experiments, the tissue sections were dewaxed by washing 3 times in fresh $100 \%$ xylene (5 min per wash), and rehydrated by 3 washes in 100\% EtOH (5 min per wash), 2 washes each in $95 \%$ EtOH (5 min per wash), $70 \% \mathrm{EtOH}, 50 \% \mathrm{EtOH}$ (ethanol was diluted in DNase/RNase-free water), 2 washes of distilled DNase/RNase-free water (5 min per wash) and 1 wash of DNase/RNase-free PBS. Pre-hybridisation and hybridisation steps included washes of DNase/ RNase-free PBS (2 washes of $5 \mathrm{~min}$ ), DNase/RNasefree PBS with $100 \mathrm{mM}$ glycine (15 $\mathrm{min})$, prior to washing in DNase/RNase-free PBS (2 washes of $5 \mathrm{~min})$. The tissue sections were permeabilized for 30 min with Tris-EDTA (TE) buffer (pH 8.0) containing $20 \mu \mathrm{g}$ RNase-free Proteinase $\mathrm{K}$ at $37^{\circ} \mathrm{C}$. Tissues were then post-fixed for $5 \mathrm{~min}$ at $4^{\circ} \mathrm{C}$ with $4 \%$ paraformaldehyde in DNase/RNase-free PBS, and fixative was removed with 4 washing steps of DNase/ RNase-free PBS (5 min per wash); acetylation of the tissue sections was not conducted. Tissues were incubated at $42^{\circ} \mathrm{C}$ for a minimum of $30 \mathrm{~min}$ in a humid environment using a tissue hybridisation station (with the pre-hybridisation buffer: $50 \%$ formamide; $4 \times$ saline sodium citrate [SSC]; $1 \times$ Dendhardt's solution; $50 \mu \mathrm{g} \mathrm{ml}^{-1}$ heparin; $5 \%$ [w/v] dextran sulphate; $250 \mu \mathrm{g} \mathrm{ml}^{-1}$ denatured sonicated salmon sperm DNA;
$0.1 \%$ [v/v] Tween-20). Pre-hybridisation buffer was drained from the tissue sections and sections were overlaid with at least $30 \mu \mathrm{l}$ of hybridisation solution $(50 \%$ formamide; $4 \times \mathrm{SSC}$ buffer; $1 \times$ Dendhardt's solution; $50 \mu \mathrm{g}$ $\mathrm{ml}^{-1}$ heparin; $5 \%$ [w/v] dextran sulphate; $250 \mu \mathrm{g} \mathrm{ml} \mathrm{g}^{-1}$ denatured sonicated salmon sperm DNA; $0.1 \%$ [v/v] Tween-20; $20 \mu \mathrm{g}$ DIG-labelled RNA probe). Tissue sections were covered with sterile RNase-free hydrophobic plastic coverslips (HydriSlip Grace BioLabs), and the tissue sections were incubated overnight at $45^{\circ} \mathrm{C}$ in a humid container. Following hybridisation, coverslips were removed by immersing slides for $5 \mathrm{~min}$ in $2 \times$ $\mathrm{SSC}$. The tissue sections were then washed twice in $2 \times \mathrm{SSC}, 1 \times \mathrm{SSC}$ and $0.1 \times \mathrm{SSC}$ for $15 \mathrm{~min}$ per wash at $37^{\circ} \mathrm{C}$ under constant agitation, and twice for $30 \mathrm{~min}$ in $0.1 \times \mathrm{SSC}$ also at $37^{\circ} \mathrm{C}$ under constant agitation. On a shaking platform, tissue sections were then washed twice for $20 \mathrm{~min}$ with $100 \mathrm{mM}$ Tris- $\mathrm{HCl}(\mathrm{pH}$ 7.5) and $150 \mathrm{mM} \mathrm{NaCl}$, and the tissue sections were covered for 30 min with a blocking reagent (Roche). The blocking reagent was decanted from the tissue sections, and before drying, the sections were overlaid with blocking reagent containing 1:1000 dilution of alkaline phosphatase conjugated anti-DIG antibody (Roche Diagnostics). Tissue sections were incubated in anti-DIG antibody solution for $2 \mathrm{~h}$ at room temperature $\left(24^{\circ} \mathrm{C}\right)$ in a humid environment (Boekel). Following incubation, the slides were washed 3 times (5 min per wash) on a shaking platform in Tris- $\mathrm{HCl}$ (pH 7.5), $150 \mathrm{mM} \mathrm{NaCl}$, and then washed for $10 \mathrm{~min}$ in $100 \mathrm{mM}$ Tris-HCl (pH 9.5) $100 \mathrm{mM} \mathrm{NaCl}, 50 \mathrm{mM}$ $\mathrm{MgCl}_{2}$, prior to the sections being coated with BCIP/ NBT (Vector) in $100 \mathrm{mM}$ Tris-HCl (pH 9.5), $100 \mathrm{mM}$ $\mathrm{NaCl}$, $50 \mathrm{mM} \mathrm{MgCl}_{2}$. Slides were incubated in BCIP/ NBT substrate solution for $3 \mathrm{~h}$ or until sufficient colour development was observed within the tissues. All coral samples were then permanently mounted, observed and imaged.

\section{RESULTS AND DISCUSSION}

\section{Cell and tissue specific host gene expression in coral tissues using ISH}

ISH techniques have been developed for coral larvae (Hayward et al. 2002, Grasso et al. 2011) and applied to localizing gene expression in developmental stages. Given the complexity of responses 


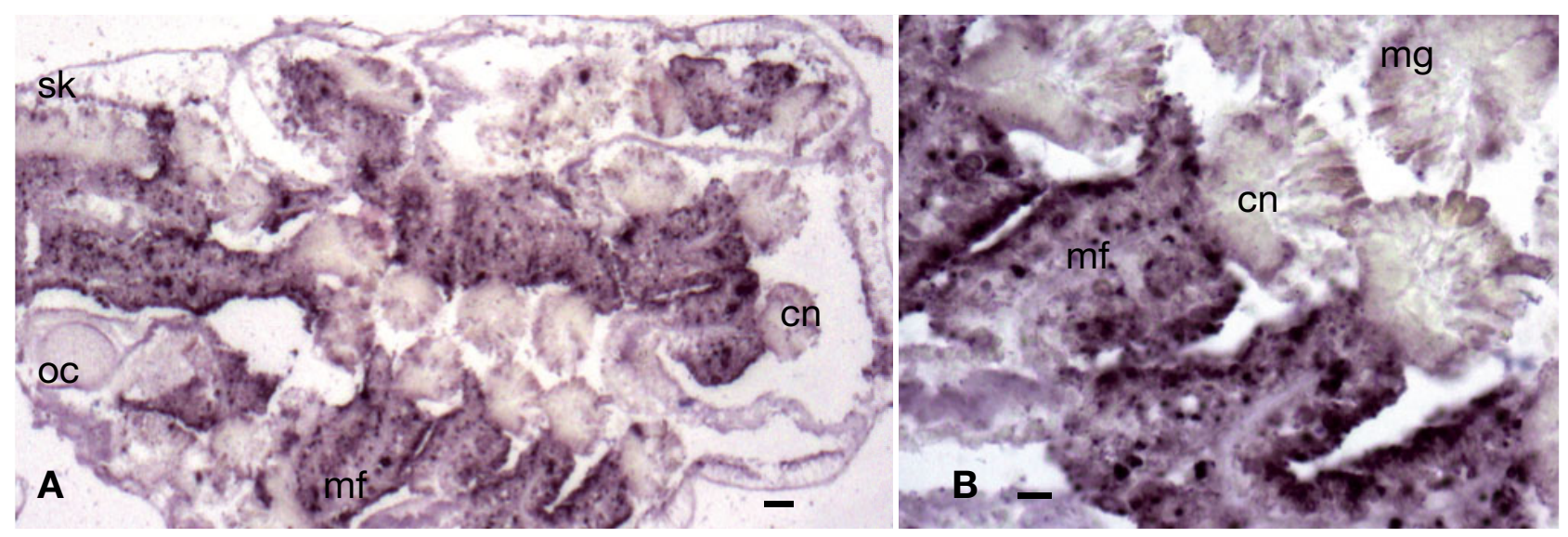

Fig. 1. In situ hybridisation using apextrin-specific gene probes demonstrates tissue- and cell-specific patterns of gene expression in healthy Acropora millepora tissue. mf: mesenterial filaments; cn: cnidoglandular band; sk: skeleton; oc: oocyte; mg: mesoglea. Scale bars $=50 \mu \mathrm{m}$

that occur in corals during a disease event, it is important that the use of ISH in adult corals is developed. Here we show the potential for gene-specific probes to differentiate cell types in situ through variable gene expression in coral cells, such as found in the mesenterial filaments of the adult gastrovascular cavity (Fig. 1), which showed expression of apextrin. The pattern of apextrin expression found within the current study is similar to the localized expression within the body wall of whole-mounted Hydra (Miller et al. 2007), indicating that the technique is appropriate to be applied to adult coral samples. Epidermal (epithelial) localized expression of cadherin is found in developmental stages of Acropora millepora (Knack 2011).

\section{Apoptotic gene expression associated with white syndrome}

Apoptosis is a cell death mechanism important in development, normal tissue turnover and disease and immune responses. Sequencing of gene fragments from $A$. hyacinthus revealed complete sequence homology of the bcl-2 family members to sequences identified in the model coral $A$. millepora and previously reported for $A$. aspera. However, the function of the bcl-2 family has not previously been characterized in reef-forming corals, nor has the localized expression of these genes during apoptotic cell death been shown. Here we demonstrate that expression of a bcl-2 family member occurs in tissues from $A$. hyacinthus coral undergoing extensive apoptotic cell death associated with the disease white syndrome. This is the first study of its kind to link morphological evidence of apoptotic cell death with the molecular machinery necessary to execute cell death in corals. Previous annotation of a coral bax-like Bcl-2 family member (Ainsworth et al. 2008) indicated minimal sequence conservation

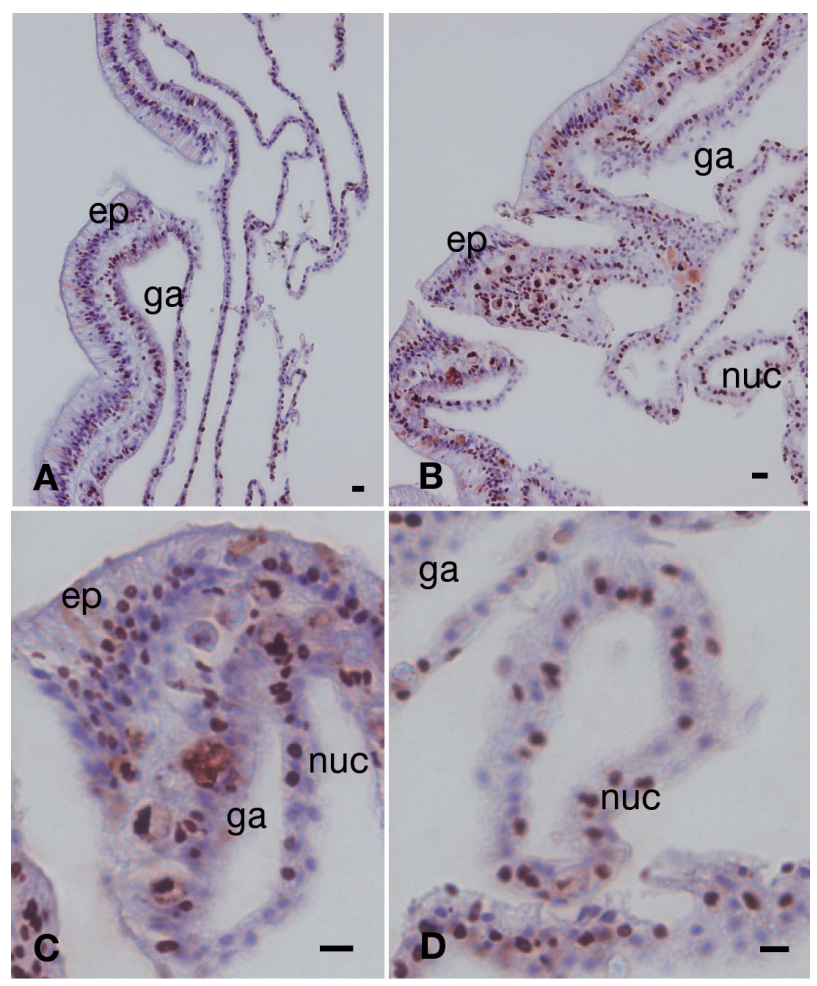

Fig. 2. In situ end labeling of fragmented DNA indicative of apoptotic cell death in white syndrome-affected Acropora hyacinthus. Nuclei of apoptotic cells are labeled red, nonapoptotic nuclei are counterstained with haematoxylin (blue). ep: epithelium; ga: gastroderm; nuc: nuclei. Scale bars $=15 \mu \mathrm{m}$ 


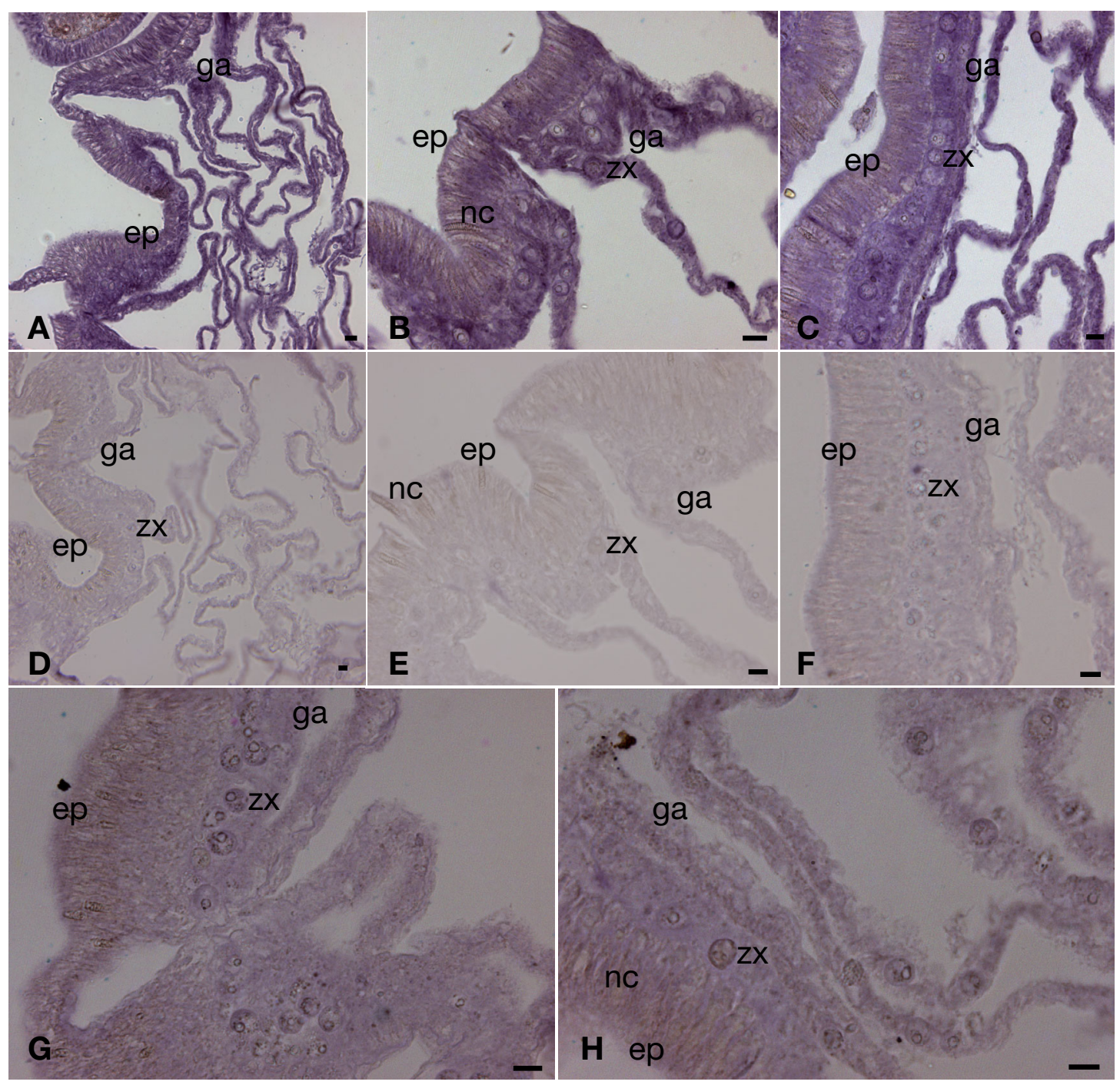

Fig. 3. (A-C) Expression of a Bcl-2 family member (pro-apoptotic gene) localized in situ of white syndrome-affected Acropora hyacinthus $(\mathrm{n}=6)$ indicated by blue colour reaction of NBC/TCIP. (D-F) Lack of gene expression of the anti-apoptotic gene bcl-2 within white syndrome-affected coral tissues. $(\mathrm{G}, \mathrm{H})$ Lack of hyribidisation of sense probes for 2 other Bcl-2 family members. ep: epidermis; ga: gastrodermis; zx: endosymbiotic dinoflagellates; nc: nematocyst. Scale bars $=15 \mu \mathrm{m}$

within the BH-4; however, further development of this field indicates BH-4 sequence conservation in the BH-4 domain of pro-apoptotic Bcl-2 family members including bax-like genes (see review by Moldoveanu et al. 2014).

Characteristics of apoptotic cell death were confirmed within $A$. hyacinthus corals undergoing white syndrome tissue loss, using ISEL of fragmented DNA and extensive staining of cells within the epidermis and gastrodermis (Fig. 2), and these characteristics were consistent with previous reports of apoptosis in coral white syndrome (Ainsworth et al. 2007b). The in situ expression of a potentially pro-apoptosis bcl-2 family member (bax-like), was high within white syn- drome-affected coral tissues when compared to healthy coral controls. Extensive gene expression was evident in the cells of each tissue layer adjacent to the disease lesions (Fig. 3A-C). Expression of bcl2 (an anti-apoptotic Bcl-2 family member) during coral white syndrome disease progression and tissue loss was not evident in the cells of the same tissue regions adjacent to the disease lesions (Fig. 3D-F), and no in situ gene expression was evident in either healthy or diseased coral tissues. As well, there was no evidence for non-specific probe binding or capture with the sense probes (Fig. 3G,H). Gene expression was also not evident in situ in healthy coral tissues (Fig. 4). 
Fig. 4. Lack of in situ expression of anti- and proapoptosis genes $(\mathrm{A}, \mathrm{B}) \mathrm{bcl}$ 2 and (C) bax in healthy tissues of the tabular acroporid coral Acropora hyacinthus $(\mathrm{n}=6)$. ep: epidermis; ga: gastrodermis; zx: endosymbiotic dinoflagellates; nc: nematocyst. Scale bars $=10 \mu \mathrm{m}$
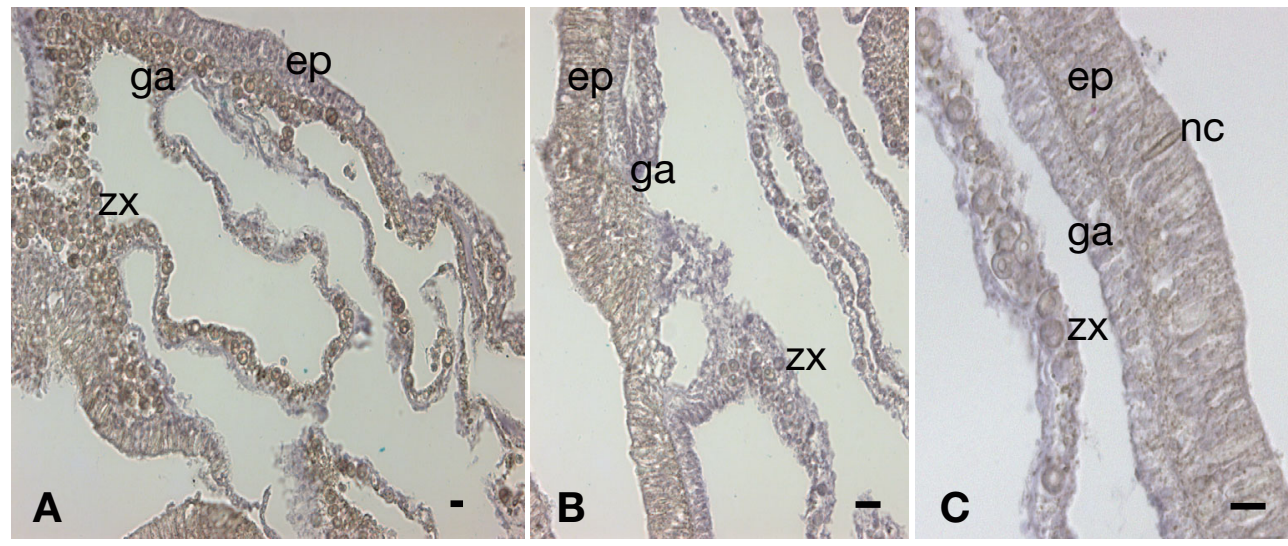

In tissue regions not directly adjacent to the disease lesions and in regions where a lower population of cells were labeled using ISEL, localisation of cell death, and potentially pro-apoptotic gene expression, within the calicodermis and desmocyte cells, where the coral host produces and anchors host tissue to the skeleton, suggests that cell death in these tissues is driving rapid tissue losses, with large regions of tissue disconnecting from the underlying coral skeleton. Up-regulation of pro-apoptotic gene expression in these regions may also be linked to rapid disruption of the host tissues, previously described as a shutdown reaction (Antonius 1977), and the loss of photoassimilate translocation (Roff et al. 2008a), which are also considered characteristic of white syndrome disease progression. This study is the first to demonstrate variable host gene expression during coral disease progression and to investigate the role of host responses in situ, in characteristic patterns of disease progression. The application of in situ expression techniques to characterize and study coral diseases provides a means to differentiate very similar and enigmatic diseases such as coral white syndrome.

White syndrome(s), and similar white diseases, have previously been associated with difficulties in localizing pathogens or microbial interactions associated with colony mortality. Sussman et al. (2008) identified 6 possible pathogens, all members of the family Vibrionaceae, associated with a white syndrome of corals from Palau reefs. In situ gene expression studies provide a means to compare disease progression in corals which are exposed to microbial pathogens within contained systems, and in fieldbased studies that find a lack of microbial involvement evident in patterns of active disease progression. By coupling in situ gene expression studies with studies of microbial pathogenicity, we can determine the impact of experimental conditions and microbial exposure on the responses and mechanisms of dis- ease progression in the coral host. The application of this technique coupled with microbial localization in situ may also provide a means to better differentiate otherwise similar disease states and understand the mechanisms which underlie disease progression and coral mortality.

\section{Caveats}

A lack of in situ gene expression of the anti-apoptotic (pro-survival) bcl-2 (gene with high conservation in all $4 \mathrm{BH}$ domains) highlights limitations of the in situ technique in studying localized gene expression during tissue homeostasis or in situations where alterations in gene expression are low. Further studies investigating in situ patterns of gene expression in healthy tissues may therefore benefit from the application of amplification and quantification steps. The current technique uses probes designed to examine conserved domains within the $b c l-2$ gene family. Other techniques (Morris et al. 2009, Grasso et al. 2011) have used gene probes to full-length gene sequences and applied a hydrolysis step to the probe preparation to facilitate penetration of the large probe into cells. The use of full-length gene probes, rather than domain-length probes, may increase the sensitivity of the technique and allow in situ investigation of genes with low expression. However, such probes are unlikely to improve sensitivity if used across different species. In circumstances where probes are required for use in multiple species, for example in comparative studies of host responses in highly similar disease states, the design of specific probes to highly conserved domain regions, such as the BH domains of bcl-2 family members, is advantageous. The use of domain-specific probes is also likely to allow differentiation of multiple similar genes within large, conserved gene families. 


\section{CONCLUSIONS}

Understanding host responses during disease, microbial infection and mortality is imperative to understanding the causes and consequences of biotic and abiotic diseases. The application of in situ gene expression techniques coupled with the localization of microbial communities will assist in determining how host-microbe interactions occur in corals and will shed light on the function of the host immune system. The application of in situ techniques is imperative if we are to not only understand the genomic complexity of lower metazoans, such as scleractinian corals, but also understand how that complexity controls cell, tissue and organism function and the response to environmental stress and pathogenicity. Magdaleno et al. (2006) developed an online database of in situ gene expression in murine development, and a similar comparative approach for documenting coral in situ gene expression may provide a means to better characterize, diagnose and understand enigmatic coral diseases such as white syndrome.

Acknowledgements. The authors thank staff at Heron Island Research Station for assistance during field collection, research funding provided by the Australian Research Council (Ainsworth DP110101284), and the manuscript reviewers.

\section{LITERATURE CITED}

Ainsworth TD, Kramasky-Winter E, Loya Y, Hoegh-Guldberg O, Fine M (2007a) Coral disease diagnostics: What's between a plague and a band? Appl Environ Microbiol 73:981-992

Ainsworth TD, Kvennefors EC, Blackall LL, Fine M, HoeghGuldberg O (2007b) Disease and cell death in white syndrome of acroporid corals on the Great Barrier Reef. Mar Biol 151:19-29

Ainsworth TD, Hoegh-Guldberg O, Heron SF, Skirving WJ, Leggat W (2008) Early cellular changes are indicators of pre-bleaching thermal stress in the coral host. J Exp Mar Biol Ecol 364:63-71

Ainsworth TD, Wasmund K, Ukani L, Seneca FO, Yellowlees D, Miller DJ, Leggat W (2011) Defining the tipping point. A complex cellular life/death balance in corals in response to stress. Sci Rep 1:160

Antonius A (1977) Coral mortality in reefs: a problem for science and management. In: Tayor DL (ed) Proc 3rd Int Coral Reef Symp, Vol 2. Rosenstiel School of Marine and Atmospheric Science, Miami, FL, p 617-623

> Ayres PG (1984) The interaction between environmental stress, injury and biotic disease physiology. Annu Rev Phytopathol 22:53-75

> Ban SS, Graham NAJ, Connolly SR (2014) Evidence for multiple stressor interactions and effects on coral reefs. Glob Change Biol 20:681-697

Brown C (1998) In situ hybridisation with riboprobes: an overview for veterinary pathologists. Vet Pathol 35:159-167
Bruno JF, Selig ER, Casey KS, Page CA and others (2007) Thermal stress and coral cover as drivers of coral disease outbreaks. PLoS Biol 5:e124

$>$ Chao DT, Korsmeyer SJ (1998) Bcl-2 family: regulators of cell death. Annu Rev Immunol 16:395-419

Czabotar PE, Lessene G, Strasser A, Adams JM (2014) Control of apoptosis by the BCL-2 protein family: implications for physiology and therapy. Nat Rev Mol Cell Biol 15:49-63

$>$ David CN, Schmidt N, Schade M, Pauly B, Alexandrova O, Bottger A (2005) Hydra and the evolution of apoptosis. Integr Comp Biol 45:631-638

> Deponte M, Becker K (2004) Plasmodium falciparum-Do killers commit suicide? Trends Parasitol 20:165-169

$>$ Dishaw LJ, Smith SL, Bigger CH (2005) Characterisation of a C3-like cDNA in a coral: phylogenetic implications. Immunogenetics 57:535-548

> Elmore S (2007) Apoptosis: a review of programmed cell death. Toxicol Pathol 35:495-516

- Grasso LC, Negri AP, Fôret S, Saint R, Hayward DC, Miller DJ, Ball EE (2011) The biology of coral metamorphosis: molecular responses of larvae to inducers of settlement and metamorphosis. Dev Biol 353:411-419

Harvell CD, Mitchell CE, Ward JR, Altizer S, Dobson AP, Ostfeld RS, Samuel MD (2002) Climate warming and disease risks for terrestrial and marine biota. Science 296: 2158-2162

> Hayward DC, Samuel G, Pontynen PC, Catmull J, Saint R, Miller DJ, Ball EE (2002) Localized expression of a dpp/ BMP2/4 ortholog in a coral embryo. Proc Natl Acad Sci USA 99:8106-8111

Itzkovitz S, van Oudenaarden A (2011) Validating transcripts with probes and imaging technology. Nat Methods 8:S12-S19

Knack BA (2011) Cell adhesion factors in cnidarians. PhD dissertation, James Cook University, Townsville

> Krediet CJ, Ritchie KB, Paul VJ, Teplitski M (2013) Coralassociated micro-organisms and their roles in promoting coral health and thwarting diseases. Proc R Soc Lond B Biol Sci 280:20122328

Kültz D (2005) Molecular and evolutionary basis of the cellular stress response. Annu Rev Physiol 67:225-257

- Kvennefors EC, Leggat W, Hoegh-Guldberg O, Degnan BM, Barnes AC (2008) An ancient and variable mannosebinding lectin from the coral Acropora millepora binds both pathogens and symbionts. Dev Comp Immunol 32: 1582-1592

Kvennefors EC, Leggat W, Kerr CC, Ainsworth TD, HoeghGuldberg O, Barnes AC (2010a) Analysis of evolutionarily conserved innate immune components in coral links immunity and symbiosis. Dev Comp Immunol 34:1219-1229

> Kvennefors EC, Sampayo E, Ridgway T, Barnes AC, HoeghGuldberg O (2010b) Bacterial communities of two ubiquitous Great Barrier Reef corals reveals both site- and species-specificity of common bacterial associates. PLoS ONE 5:e10401

> Lesser MP, Bythell JC, Gates RD, Johnston RW, HoeghGuldberg O (2007) Are infectious diseases really killing corals? Alternative interpretations of the experimental and ecological data. J Exp Mar Biol Ecol 346:36-44

> Levsky JM, Singer RH (2003) Fluorescence in situ hybridization: past, present and future. J Cell Sci 116:2833-2838

> Loker ES, Adema CM, Zhang SM, Kepler TB (2004) Invertebrate immune systems - not homogeneous, not simple, not well understood. Immunol Rev 198:10-24 
Magdaleno S, Jensen P, Brumwell CL, Seal A and others (2006) BGEM: an in situ hybridization database of gene expression in the embryonic and adult mouse nervous system. PLoS Biol 4:e86

Miller DJ, Hemmrich G, Ball EE, Hayward DC and others (2007) The innate immune repertoire in Cnidariaancestral complexity and stochastic gene loss. Genome Biol 8:R59

Moldoveanu T, Follis AJ, Kriwacki RW, Green DR (2014) Many players in BCL-2 family affairs. Trends Biochem Sci 39:101-111

Morris CA, Benson E, White-Cooper H (2009) Determination of gene expression patterns using in situ hybridization to Drosophila testes. Nat Protoc 4:1807-1819

> Mouchka ME, Hewson I, Harvell CD (2010) Coralassociated bacterial assemblages: current knowledge and the potential for climate-driven impacts. Integr Comp Biol 50:662-674

Mydlarz LD, Harvell CD (2007) Peroxidase activity and inducibility in the sea fan coral exposed to a fungal pathogen. Comp Biochem Physiol A Mol Integr Physiol 146:54-62

> Mydlarz LD, Holthouse SF, Peters EC, Harvell CD (2008) Cellular responses in sea fan corals: granular amoebocytes react to pathogen and climate stressors. PLoS ONE 3:e1811

Mydlarz LD, Couch CS, Weil E, Smith G, Harvell CD (2009) Immune defenses of healthy, bleached and diseased Montastraea faveolata during a natural bleaching event. Dis Aquat Org 87:67-78

Mydlarz LD, McGinty ES, Drew Harvell C (2010) What are the physiological and immunological responses of coral to climate warming and disease? J Exp Biol 213:934-945

Palmer CV, Roth MS, Gates RD (2009) Red fluorescent protein responsible for pigmentation in trematode-infected Porites compressa tissues. Biol Bull (Woods Hole) 216: 68-74

Palmer CV, Bythell JC, Willis BL (2010) Levels of immunity parameters underpin bleaching and disease susceptibility of reef corals. FASEB J 24:1935-1946

Palmer CV, Traylor-Knowles NG, Willis BL, Bythell JC (2011) Corals use similar immune cells and woundhealing processes as those of higher organisms. PLoS ONE 6:e23992

Pernice M, Dunn SR, Miard T, Dufour S, Dove S, Hoegh-

Editorial responsibility: Garriet Smith,

Aiken, South Carolina, USA
Guldberg O (2011) Regulation of apoptotic mediators reveals dynamic responses to thermal stress in the reef building coral Acropora millepora. PLoS ONE 6:e16095

> Pollock FJ, Morris PJ, Willis BL, Bourne DG (2011) The urgent need for robust coral disease diagnostics. PLoS Pathog 7:e1002183

Roff G, Hoegh-Guldberg O, Fine M (2006) Intra-colonial response to Acroporid 'white syndrome' lesions in tabular Acropora spp. (Scleractinia). Coral Reefs 25:255-264

Roff G, Kvennefors E, Ulstrup K, Fine M, Hoegh-Guldberg O (2008a) Coral disease physiology: the impact of Acroporid white syndrome on Symbiodinium. Coral Reefs 27: 373-377

Roff G, Ulstrup KE, Fine M, Ralph PJ, Hoegh-Guldberg O (2008b) Spatial heterogeneity of photosynthetic activity within diseased coral from the Great Barrier Reef. J Phycol 44:526-538

> Sussman M, Willis BL, Victor S, Bourne DG (2008) Coral pathogens identified for White Syndrome (WS) epizootics in the Indo-Pacific. PLoS ONE 3:e2393

Sutherland KP, Porter JW, Torres C (2004) Disease and immunity in Caribbean and Indo-Pacific zooxanthellate corals. Mar Ecol Prog Ser 266:273-302

van de Water JAJM, Leggat W, Bourne DG, van Oppen MJH, Willis BL, Ainsworth TD (2015) Elevated seawater temperatures have a limited impact on the coral immune response following physical damage. Hydrobiologia 759: 201-214

Weinrauch Y, Zychlinsky A (1999) The induction of apoptosis by bacterial pathogens. Annu Rev Microbiol 53: 155-187

Willis B, Page C, Dinsdale E (2004) Coral disease on the Great Barrier Reef. In: Rosenberg E, Loya Y (eds) Coral health and disease. Springer, Berlin, $p$

> Work T, Meteyer C (2014) To understand coral disease, look at coral cells. EcoHealth 11:610-618

> Work TM, Richardson LL, Reynolds TL, Willis BL (2008) Biomedical and veterinary science can increase our understanding of coral disease. J Exp Mar Biol Ecol 362:63-70

> Wunderlich Z, Bragdon MD, DePace AH (2014) Comparing mRNA levels using in situ hybridization of a target gene and co-stain. Methods 68:233-241

Zmasek CM, Zhang Q, Ye Y, Godzik A (2007) Surprising complexity of the ancestral apoptosis network. Genome Biol 8:R226

Submitted: October 23, 2014; Accepted: May 15, 2015 Proofs received from author(s): November 6, 2015 